$\mathrm{Nr} 2(65), 2020$, s. 11-24

https://doi.org/10.12797/Politeja.17.2020.65.01

\author{
Magdalena SARYUSZ-WOLSKA iD \\ Uniwersytet Łódzki \\ magdalena.saryusz-wolska@uni.lodz.pl
}

\title{
PRZESZŁOŚĆ I PRZYSZŁOŚĆ BADAŃ PAMIĘCI
}

\section{CZY POTRZEBUJEMY NOWEJ DYSCYPLINY?}

ABSTRACT The Past and the Future of Memory Research. Do We Need a New Discipline? The article discusses the status of memory studies as an academic discipline as well as their complex terminology and methodology. The author focuses on examples from Poland and Germany, arguing that in spite of many initiatives, such as academic associations or academic journals, memory studies are an interdisciplinary field rather than an academic discipline. The term 'memory' is usually used as a metaphor or analytical tool instead of being the actual object of research. The current popularity of historical issues in the public sphere requires a more precise and disciplined approach to the topic.

Keywords: memory studies, memory turn, collective memory, academic communication

Słowa kluczowe: badania pamięci, zwrot pamięciowy, pamięć zbiorowa, komunikacja naukowa 
W e wstępie do głośnej książki Pamięć kulturowa. Pismo, zapamiętywanie i polityczna tożsamość $w$ cywilizacjach starożytnych Jan Assmann sugerował, że wkrótce nadejdzie zwrot pamięciowy: Wszystko przemawia za tym, że kwestia pamięci wptynie na wytworzenie nowego paradygmatu nauk o kulturze, który $w$ nowym świetle postawi rozmaite zjawiska i dziedziny - sztukę i literaturę, politykę i spoteczeństwo, religię i pra$w o$ - pisal ${ }^{1}$. Pierwszy raz słowa te zostały opublikowane w 1992 roku, dokładnie w tym samym czasie, kiedy inny uczony w Stanach Zjednoczonych, W.J. Thomas Mitchell, ogłaszał nadejście zwrotu piktorialnego ${ }^{2}$. Wydaje się, oba zwroty, pamięciowy i wizualny, przebiegały pod wieloma względami podobnie. Niektórzy aktorzy tych procesów, jak np. Mieke Bal, odcisnęli zresztą swoje ślady na obu polach. Debata na temat studiów wizualnych jest w Polsce doskonale znana ${ }^{3}$. Tymczasem dyskusja o statusie badań pamięci cały czas się toczy.

Zarówno Mitchell, jak i Assmann szukali dróg rozwiązania problemów, które dostrzegali w widocznej wówczas zmianie kulturowej. Ostatnie dwie dekady XX wieku to bowiem czas intensywnej ekspansji mediów wizualnych, a także nowych społecznych koncepcji czasu, czego najlepszym przykładem była głośna teza Francisa Fukuyamy o końcu historii (nie do utrzymania z dzisiejszego punktu widzenia). Zjawiska te stanowiły wyzwania nie do objęcia w ramach dotychczasowego porządku dyscyplin naukowych. Mitchell i Assmann nie byli oczywiście jedynymi teoretykami, którzy podjęli refleksję na polach przekraczających ówczesne podziały nauki, ale potraktuję ich - zwłaszcza zaś Assmanna - jako reprezentatywnych przedstawicieli nowych trendów intelektualnych, formujących się na przełomie XX i XXI wieku.

Mitchell mówił w trybie oznajmującym, zdecydowanym tonem i w ten sposób jego deklaracja stała się performatywnym aktem założycielskim nowego zwrotu. Jego tekst wyznaczył przełom w humanistyce, zwracając uwagę na wizualny charakter rzeczywistości kulturowej. Otworzył także drogę do powołania studiów wizualnych, które przynajmniej w krajach anglosaskich szybko awansowały do miana osobnej dyscypliny. W przeciwieństwie do Mitchella, Assmann wypowiadał swoją prognozę na temat zwrotu pamięciowego w trybie przypuszczającym, ostrożnie sugerując, że kategoria pamięci będzie miała coraz większe znaczenie w dyskursie humanistyki zachodniej.

J. Assmann, Pamięć kulturowa. Pismo, zapamiętywanie i polityczna tożsamość w cywilizacjach starożytnych, przeł. A. Kryczyńska-Pham, Warszawa 2008, s. 27.

2 W.J.T. Mitchell, Zwrot piktorialny, przeł. M. Drabek, „Kultura Popularna” 2009, nr 1, s. 4-19.

3 Por. m.in. przekłady tekstów: W.J.T. Mitchell, Pokazujac widzenie: krytyka kultury wizualnej, przeł. M. Bryl, „Artium Quaestiones” 2006, nr 17; N. Mirzoeff, Podmiot kultury wizualnej, przeł. M. Bryl, "Artium Quaestiones” 2006, nr 17; M. Bal, Wizualny esencjalizm i przedmiot kultury wizualnej, przel. M. Bryl, „Artium Quaestiones” 2006, nr 17. 


\section{ZWROT PAMIĘCIOWY I FORMOWANIE SIĘ NOWYCH BADAŃ PAMIĘCI}

Jan Assmann z wykształcenia jest archeologiem i przez lata zajmował się przede wszystkim mechanizmami transferu wiedzy o przeszłości w cywilizacjach starożytnych. Budując typologię pamięci, którą podzielił na komunikacyjną i kulturową, czyli - mówiąc najprościej - przekazywaną ustnie i utrwalaną zewnętrznie, trafił jednak w nerw czasu. Na początku lat 90. XX wieku zmiana pokoleniowa stała się bardzo widoczna: świadków drugiej wojny światowej zaczęło coraz szybciej ubywać. Ludzie urodzeni w pierwszych latach XX wieku, którzy przeżyli pierwszą wojnę jako dzieci i młodzież, drugą zaś już jako dorosłe osoby, wydawali ostatnie osobiste i bezpośrednie świadectwa. W tym czasie dokonywał się transfer od pamięci komunikacyjnej do kulturowej - rosła świadomość, że pamięć o wojnie i Zagładzie należy utrwalić zarówno w formie archiwum, jak i popularnych tekstów kulturowych. Kategorie Assmanna pozwoliły ten proces analitycznie opisać. Równolegle w innych krajach europejskich (to ciekawe, że nie w Stanach Zjednoczonych) powstawały nośne koncepcje dotyczące kulturowych mechanizmów przekazywania i utrwalania przeszłości: Pierre Nora kierował na przełomie lat 80. i 90. XX wieku monumentalnym projektem dotyczącym miejsc pamięci Francji (Les lieux de mémoire), a Paul Connerton odpowiadał w 1989 roku na pytanie Jak spoteczeństwa pamiętają? $\mathrm{w}$ książce pod tym samym tytułem ${ }^{4}$.

Bez wątpienia zatem mnemonic turn, który przewidywał Assmann, rzeczywiście nastąpił. Jeśli przyjąć kryteria zwrotu, które proponuje Doris Bachmann-Medick w książce Cultural turns, to zwrot pamięciowy spełnia oba wymogi: jest interdyscyplinarny i analityczny ${ }^{5}$. Już w połowie lat 80 . XX wieku - mniej więcej w czasie, gdy Pierre Nora realizował projekt miejsc pamięci - w różnych ośrodkach naukowych krystalizowało się wspólne pytanie badawcze dotyczące kulturowej i społecznej funkcji historii w teraźniejszości, na które nie można było wypracować odpowiedzi w ramach jednej, ugruntowanej dyscypliny. W sam tylko projekt Nory zaangażowani byli historycy, socjologowie czy literaturoznawcy. Bachmann-Medick podkreśla jednak, że samo tylko interdyscyplinarne wyzwanie nie wystarcza do mówienia o zwrocie. Owo kluczowe dla zwrotu pojęcie - w tym wypadku „pamięć" - musi przybrać cechy kategorii analitycznej.

Istnieje co najmniej kilka dowodów na to, że pamięć spełnia także to drugie, sformułowane przez Bachmann-Medick, kryterium. Na poziomie społecznym, zbiorowym czy kulturowym „pamięć” zawsze jest metaforą - jak słusznie zauważała Barbara Szacka w połowie lat 90. XX wieku' ${ }^{6}$ gdy pojęcie to zyskiwało popularność także w polskich badaniach. Społeczeństwa ani kultury nie mają pamięci w takim znaczeniu, w jakim posiadają ją pojedyncze jednostki. Dosłowne rozumienie pamięci wymaga określonej

P. Connerton, Jak spoteczeństwa pamiętają?, przeł. M. Napiórkowski, Warszawa 2012.

5 D. Bachmann-Medick, Cultural Turns. Nowe kierunki w naukach o kulturze, przel. K. Krzemieniowa, Warszawa 2012.

6 B. Szacka, O pamięci spotecznej, „Znak” 1995, nr 5, s. 68. 
budowy neuronów i obecności konkretnych białek w mózgu. Ani społeczeństwa, ani kultury nie mogą się nimi, rzecz jasna, wykazać. Mimo to mówimy jednak o pamięci społecznej, pamięci zbiorowej czy pamięci kulturowej, aby określić zjawisko obecności i istotności przeszłości w teraźniejszości. Zanim prace Nory, Assmanna czy Connertona zyskały popularność w Polsce, socjologowie, wśród nich Szacka, posługiwali się na ogół terminem „świadomość historyczna” - skądinąd też metaforycznym. Pamięć nie jest zatem bezpośrednim przedmiotem badawczym. To nie ją analizujemy w pracach naukowych, lecz raczej przejawy i wskaźniki społecznego czy kulturowego zainteresowania przeszłością. Pojęcie pamięci oraz wszelkie pojęcia pokrewne są natomiast poręcznymi, metaforycznymi i zrozumiałymi narzędziami, pozwalającymi opisać analizowane zjawiska. Mówiąc językiem Bachmann-Medick, „pamięć” jest przede wszystkim kategorią analityczną.

Taki sposób rozumienia pamięci obecny jest $\mathrm{w}$ dyskursie naukowym niemal od momentu wyłonienia się tego tematu w refleksji teoretycznej lat międzywojennych, czyli od czasów Maurice'a Halbwachsa, Aby'ego Warburga, Waltera Benjamina, a także mniej znanych w tym kontekście Stefana Czarnowskiego czy Lwa Wygotskiego. Ci europejscy badacze zaproponowali m.in. takie pojęcia, jak „pamięć zbiorowa” (Halbwachs), „pamięć społeczna”, „pamięć obrazów” (Warburg), „anioł historii” (Benjamin), „dawność w teraźniejszości” (Czarnowski), „pamięć socjokulturowa” (Wygotski). Choć byli to badacze z różnych krajów, reprezentujący różne dyscypliny - od psychologii po filozofię - wszystkich nurtował podobny problem, a mianowicie istnienie wspólnych, ponadjednostkowych wyobrażeń o przeszłości. Nie wszyscy jednak używali pojęcia „pamięć" na opisanie tego zjawiska w różnych jego wcieleniach.

Podczas drugiej fali badań pamięci, czyli mniej więcej od połowy lat 80 . XX wieku (choć we francuskiej szkole Annales temat wyłonił się już pod koniec lat 70. - np. w pracach Jacques’a Le Goffa), za prekursorów tej dyscypliny uznano przede wszystkim Halbwachsa oraz Warburga. To na nich powołują się Nora czy Assmann we wprowadzeniach do swoich najważniejszych książek. Doniosła rola, jaką przypisano międzywojennym badaczom, nie wynikała jednak z ich propozycji teoretycznych, które na ogół wytrzymały próby czasu, lecz przede wszystkim z wprowadzenia użytecznego języka i obrazowych metafor. Jednocześnie w ostatnich dwóch dekadach XX wieku trwał proces wynajdowania kolejnych pojęć, takich jak wymienione wcześniej: miejsca pamięci czy pamięć kulturowa i komunikacyjna.

Obecnie - jak argumentuje Astrid Erll - zmierzamy ku trzeciej fali badań pamię$\mathrm{ci}^{7}$. Charakteryzuje się ona badaniami nad globalnymi schematami pamiętania, analizą transnarodowych przemieszczeń i dynamiki pamięci. Rozwój ten nie zatrzymał jednak inflacji terminologicznej. Przeciwnie, do zbioru pojęć już ustabilizowanych należy obecnie dodać kolejne: „wędrówki pamięci” (Erll) czy „pamięć wielokierunkowa” (Michael Rothberg). Niezmienna pozostaje też praktyka, w której pamięć jest przede wszystkim narzędziem opisu i analizy, mniej zaś przedmiotem badawczym. Idea pamięci zbiorowej (pierwsza fala), kulturowej (druga fala) czy wielokierunkowej (trzecia fala)

A. Erll, Kultura pamięci. Wprowadzenie, przeł. A. Teperek, Warszawa 2018, s. 264-269. 
ma służyć zrozumieniu ludzkiej potrzeby przywoływania lub wymazywania przeszłości w/z teraźniejszości. W gruncie rzeczy zawsze chodzi o społeczną i kulturową funkcjonalność tego, co minione.

\section{INSTYTUCJONALIZACJA BADAŃ PAMIĘCI}

Jak zatem wygląda sytuacja badań pamięci potraktowanych szerzej niż zwrot - analogicznie np. do studiów wizualnych, które mają mocną pozycję w krajobrazie akademickim i w wielu krajach zyskały już status dyscypliny naukowej? Logiczną konsekwencją wyłonienia się jednego, dominującego tematu czy nurtu badawczego wydają się działania zmierzające do jego ustabilizowania nie tylko w języku, ale i w instytucjonalnym systemie nauki. Rozpocznę od samego pojęcia „badanie pamięci”, wobec którego nie ma w polskich badaniach pełnej zgody. Angielski termin memory studies funkcjonuje w różnych przekładach. Kornelia Kończal i Joanna Wawrzyniak proponują „pamięcioznawstwo"8. W niektórych publikacjach pojawia się słowo „pamięciologia”, pisane jednak na ogół w cudzysłowie, który sygnalizuje rezerwę wobec tego tworu językowego?. Określenie memory studies bywa także tłumaczone opisowo jako „studia nad pamięcią”, „studia pamięciowe”, „badania nad pamięcią” lub „badania pamięci” ${ }^{10}$. Ostatnie sformułowanie - za którym się opowiadam - zakłada szeroki zakres różnych badań, w przeciwieństwie do "pamięcioznawstwa” czy „pamięciologii” sugerujących dyscyplinarną jednolitość. Ponadto „badania pamięci” - w odróżnieniu od badań nad pamięcią - nie posługują się obrazem nauki, która stoi ponad obszarem swojego zainteresowania, wywyższa się w relacji do własnego przedmiotu. Badania pamięci są częścią dyskursu pamięciowego.

Sam spór o nazwę nie mówi jednak wiele o statusie badań pamięci, zwłaszcza że problem ogranicza się do polskiego obszaru językowego, podczas gdy w międzynarodowych publikacjach panuje zgodność w sprawie terminu memory studies. O umacnianiu się tego pola badań świadczą jednak liczne inicjatywy jego instytucjonalizacji. Poniżej skoncentruję się tylko na wybranych przykładach z Polski, Niemiec i Stanów Zjednoczonych, gdyż dokładne omówienie tego procesu w szerszej skali wymagałoby osobnego artykułu: w 2004 roku przy Instytucie Kulturoznawczym w Essen w Niemczech (Kulturwissenschaftliches Institut Essen) powstało Center for Interdisciplinary Memory Research; w 2008 roku wydawnictwo Sage wydało pierwszy numer czasopisma „Memory Studies”, które zyskało bardzo wysoką rangę w trakcie dziesięciu lat swojej działalności; w 2010 roku w Instytucie Socjologii na Uniwersytecie Warszawskim

$8 \quad$ K. Kończal, Wprowadzenie, [w:] (Kon)teksty pamięci. Antologia, red. K. Kończal, Warszawa 2014; K. Kończal, J. Wawrzyniak, Polskie badania pamięcioznawcze: tradycje, koncepcje, (nie)ciagtości, „Kultura i Społeczeństwo" 2011, nr 4.

9 M. Saryusz-Wolska, Wprowadzenie, [w:] Pamięć zbiorowa i kulturowa. Wspótczesna perspektywa niemiecka, red. M. Saryusz-Wolska, Kraków 2009.

10 W tym ostatnim brzmieniu m.in. w: Modi memorandi. Leksykon kultury pamięci, red. M. Saryusz-Wolska, R. Traba, współpr. J. Kalicka, Warszawa 2014. 
powstała Międzyzakładowa Pracownia Pamięci Społecznej; w kolejnym roku Europejska Sieć Pamięć i Solidarność we współpracy z tymże Instytutem Socjologii UW rozpoczęła organizację dorocznych konferencji „Genealogies of Memory”; od 2012 roku na uniwersytecie we Frankfurcie nad Menem prężnie działa „The Frankfurt Memory Studies Platform"; w 2014 roku Roma Sendyka utworzyła na Uniwersytecie Jagiellońskim Ośrodek Badań nad Kulturami Pamięci. Tematycznych numerów samych tylko polskich czasopism, które były poświęcone pamięci, nie sposób dziś zliczyć: od „Kultury i Społeczeństwa” w 2001 roku, przez „Konteksty” w 2003 i 2004 roku, „Kulturę Współczesną” (wielokrotnie), „Sensus Historiae”, „Teksty Drugie”, „Stan Rzeczy”, „Studia Kulturoznawcze" i wiele innych. Pamięć okazała się zatem atrakcyjnym tematem dla czasopism wydawanych w ośrodkach socjologicznych, antropologicznych, kulturoznawczych, literaturoznawczych czy historycznych.

Zwieńczeniem działań instytucjonalizacyjnych, widocznych nie tylko w Polsce czy w Niemczech, było powołanie w 2016 roku międzynarodowego stowarzyszenia badań pamięci: Memory Studies Association. Skoro zatem pamięć ma już swoje stowarzyszenie naukowe, własne instytuty i czasopisma, to przynajmniej w wymiarze formalnym zaczyna zasługiwać na miano osobnej dyscypliny czy subdyscypliny naukowej. W polskim systemie nauki „pamięć historyczna” pojawia się expressis verbis na liście paneli Narodowego Centrum Nauki (w panelu HS3 5). Symptomatyczne jest natomiast, że nie prowadzi się na rodzimych uniwersytetach żadnego kierunku studiów kształcącego w tym obszarze. Pojedyncze zajęcia na ten temat pojawiają się na różnych uczelniach i wydziałach w całej Polsce. Z internetowej bazy ludzi nauki wynika, że większość polskich badaczy pamięci doktoryzowała i habilitowała się w takich dyscyplinach, jak: historia, socjologia lub kulturoznawstwo. W skali międzynarodowej sytuacja pamięci jako obszaru dydaktycznego i dyscypliny, w której można zdobywać stopnie naukowe, wygląda jednak różnie - w zależności od systemowych rozwiązań w poszczególnych krajach. Przykład polski nie jest tu zatem reprezentatywny.

Bez wątpienia badania pamięci są atrakcyjnym polem dla humanistów. Po pierwsze, jako obszar interdyscyplinarny, przełamują granice poszczególnych dziedzin nauki, dobrze wpisują się w politykę grantów i projektów, które zwykle wymagają jednoczesnego działania w różnych dyscyplinach. Po drugie, badania pamięci są tematem publicystycznie atrakcyjnym, więc osoby zajmujące się tą problematyką relatywnie częściej niż inni humaniści piszą czy mówią dla mediów masowych, co zwiększa ich rozpoznawalność. Po trzecie, badania pamięci mają pewien potencjał „stosowalności”, np. w sferze muzealnictwa czy konsultowania popularnych produkcji historycznych. Rzadkie potaczenie spotecznego znaczenia i intelektualnego wyzwania pozwala wyjaśnić popularność tego pola ${ }^{11}$ - podpowiadał Wulf Kansteiner, omawiając mocne i słabe strony badań pamięci na przełomie tysiącleci. Last but not least - pamięć jest tematem politycznym. Od czasu powołania Instytutu Pamięci Narodowej, a później od momentów ogłaszania kolejnych polityk historycznych badania pamięci w Polsce rzeczywiście wpisują się

11 W. Kansteiner, Szukanie znaczeń w pamięci: metodologiczna krytyka pamięcioznawstwa, [w:] (Kon) teksty pamięci..., s. 227. 
dyskurs polityki - zarówno na rzecz, jak i przeciw politycznym interwencjom w historię. W ostatnich miesiącach badacze pamięci wielokrotnie wypowiadali się w mediach w sprawach związanych ze sporem wokół Muzeum II Wojny Światowej, żądań reparacji wojennych czy nowelizacji ustawy o IPN. Intensyfikacja polityki historycznej pociąga zatem za sobą dalszą instytucjonalizację omawianego tu pola badawczego - rośnie bowiem zapotrzebowanie na uczonych, którzy będą analizowali i wyjaśniali zjawiska związane ze społeczną funkcjonalnością przeszłości. A że „pamięć” sprawdziła się jako użyteczne i powszechnie zrozumiałe narzędzie interpretacyjne, to zapewne proces ten będzie postępowal pod szyldem badań pamięci, studiów pamięciowych czy pamięcioznawstwa.

\section{DYLEMATY KOMUNIKACJI W BADANIACH PAMIĘCI}

Wymienionym wyżej działaniom w sferze instytucjonalnej towarzyszyły różne projekty badawcze. W tym miejscu chciałabym skoncentrować się na dwóch, które pozwolą mi pokazać potencjał i problemy badań pamięci. W 2006 roku, a zatem relatywnie wcześnie, biorąc pod uwagę nakreślony rozwój wypadków, Robert Traba zainicjował w Centrum Badań Historycznych Polskiej Akademii Nauk w Berlinie długi (jak się później okazało dziewięcioletni) projekt „Polsko-Niemieckie Miejsca Pamięci”. W tamtym czasie był to największy projekt polskiej humanistyki - ponad sto pięćdziesiąt osób, głównie z Polski i Niemiec, aktywnie pracowało nad opracowaniem ponad stu pojęć, będących wspólnymi lub paralelnymi miejscami pamięci polskiej i niemieckiej. Punktem wyjścia była koncepcja Pierre’a Nory, ale zastosowana w kontekście bilateralnym i rozszerzona o teorię historii wzajemnych oddziaływań Klausa Zernacka. Ten niedawno zmarty historyk już w latach 70. XX wieku postulowal, aby narodowych historiografii nie pisać w izolacji: każda historia narodowa rozwija się w relacji do innych - zwykle sąsiedzkich - historii narodowych ${ }^{12}$. W rezultacie powstało dziewięć tomów: cztery po polsku i pięć po niemiecku. Dodatkowy tom niemiecki jest tu szczególnie istotny. Już w początkowej fazie projektu okazało się bowiem, że niemieccy uczestnicy projektu mieli ograniczoną wiedzę o tradycji polskich badań pamięci, polscy uczeni zaś nie byli, na ogół, na bieżąco z debatą niemiecką. Przekładało się to na wymierne trudności w komunikacji naukowej. Dlatego powstał dodatkowy tom, zawierający niemieckie przekłady fundamentalnych polskich tekstów, m.in. autorstwa Stefana Czarnowskiego, Stanisława Ossowskiego, Niny Assorodobraj, Elżbiety Tarkowskiej, Barbary Szackiej, Andrzeja Szpocińskiego, Joanny Kurczewskiej czy Kai Kaźmierskiej. Ponadto, niejako równolegle do projektu ukazało się kilka książek, które reagowały na zapotrzebowanie na odpowiednie teksty w Polsce. Warto tu wymienić zredagowaną przez Kornelię Kończal antologię (Kon)teksty pamięci, która zawiera podstawowe teksty zachodnich

12 O koncepcji Zernacka i jej znaczeniu dla koncepcji polsko-niemieckich miejsc pamięci por. R. Traba, H.H. Hahn, O czym (nie) opowiadaja polsko-niemieckie miejsca pamięci, [w:] Polsko-niemieckie miejsca pamięci, t. 1, red. R. Traba, H.H. Hahn, współpr. K. Kończal, M. Górny, Warszawa 2015. 
badaczy. Mówiąc językiem trzeciej fali badań pamięci, publikacje te miały umożliwić transnarodowy transfer dyskursu pamięci.

Czym zaowocowało doświadczenie zebrane podczas pracy przy Polsko-niemieckich miejscach pamięci? Między innymi świadomością barier komunikacyjnych w gronie około stu pięćdziesięciu osób o podobnych zainteresowaniach naukowych i znających przeważnie oba języki. Niemal dekada realizacji tego projektu była - obok satysfakcji z publikacji dziewięciu tomów - także lekcją pokory i weryfikacji wielu tez dotyczących rzekomej interdyscyplinaryzacji i internacjonalizacji nauki. W obliczu codziennej praktyki badawczej, odsłaniającej różnice w rozumieniu podstawowych pojęć w tym względnie jednolitym gronie, zasadne wydawało się pytanie o to, jak porozumiewają się badacze o bardziej zróżnicowanych kompetencjach językowych, dyscyplinarnych i przedmiotowych.

$\mathrm{Z}$ tego namysłu zrodził się kolejny projekt, a mianowicie leksykon kultury pamięci Modi memorandi. Trudności komunikacyjne między badaczami nie wynikają bynajmniej z braku zainteresowania, lecz z funkcjonowania w różnych polach i sieciach, w których czytane i polecane są różne lektury oraz omawiane są różne projekty. Dziś ten mechanizm „bańki wiedzy” wzmacniany jest przez media społecznościowe i kulturę algorytmu: księgarnia internetowa podpowiada, co możemy jeszcze przeczytać, na podstawie tego, co właśnie kupiliśmy; portale, takie jak academia.edu czy researchgate. net sugerują, kogo mamy obserwować na podstawie tego, czyje badania i publikacje już śledzimy. Rzecz jasna, tradycyjną metodą wyszukiwania literatury w katalogach i bazach bibliotecznych można pokonać algorytm, ale nowości wydawniczych artykułów jest tak wiele, że trudno zapanować nad zalewem wiedzy.

Leksykon Modi memorandi był więc próbą uporządkowania terminologii, która pojawia się w badaniach pamięci, w różnych dyscyplinach i tradycjach akademickich. Mieliśmy nadzieję, że dzięki tej publikacji pomożemy naukowcom - przynajmniej w Polsce - pokonać bariery związane z zamknięciem we własnych polach badawczych. Granicą, której celowo nie przekraczaliśmy, były nauki techniczne i nauki o życiu, mimo że pamięć jest także ważnym pojęciem informatyki czy neurofizjologii. Wystarczającym wyzwaniem okazały się jednak próby przerzucenia mostów między niektórymi naukami społecznymi (np. psychologią) a humanistycznymi (np. kulturoznawstwem). Dla przykładu: podczas gdy dla kulturoznawców pojęcia fetysza czy wyparcia stanowią fundament terminologii analitycznej opartej na psychoanalizie, dla psychologa są przestarzałymi i nienaukowymi kategoriami, których nie stosuje się we współczesnych badaniach. Sam proces konstruowania listy pojęć leksykonu oraz budowania zespołu, który go pisał, trwał w konsekwencji dwa lata. W tym czasie udało się wyodrębnić dwieście cztery pojęcia, które w dostępnej wówczas (czyli w 2012 roku) literaturze przedmiotu budowały terminologię badań pamięci. Sto osiemdziesiąt haseł doczekało się ostatecznego opracowania. Po długich dyskusjach zawężony został jednak obszar przedmiotowy leksykonu - $\mathrm{z}$,interdyscyplinarnego leksykonu terminów pamięci zbiorowej”, o którym była mowa we wniosku o finansowanie, książka stała się leksykonem „kultury pamięci”. Psychologiczne i społeczne aspekty pamięci zbiorowej pełnią w niej funkcję dopełniającą, ustąpiwszy miejsca pojęciom związanym z kulturowymi kontekstami pamiętania. 
Leksykon Modi memorandi podąża za definicją kultury pamięci według niemieckiego historyka Christopha Corneließena, który twierdzi: Sensowne wydaje się rozumienie "kultury pamięci” jako formalnego pojęcia nadrzędnego dla wszelkich możliwych form świadomej pamięci o wydarzeniach historycznych, osobistościach i procesach. Pojęcie to obejmuje zatem, oprócz form ahistorycznej czy wręcz antyhistorycznej pamięci zbiorowej, wszystkie inne sposoby przedstawiania historii, $w$ tym dyskurs naukowo-historyczny oraz „prywatne” wspomnienia, o ile zostawity one ślady w sferze publicznej ${ }^{13}$. Nasza refleksja nad stanem badań pamięci, a w szczególności nad ich terminologią i komunikacją naukową nie wyrastała z próżni. Problemy, z którymi mierzyliśmy się w Polsce i Niemczech, były diagnozowane także $w$ innych miejscach. Tematem przewodnim pierwszego numeru czasopisma „Memory Studies” było hasło: Memory Studies: for and against. Szukając przyczyn „braku dyscypliny”, Jeffrey Olick zauważał: Najważniejszy jest brak podstawowej zgody w sprawie kanonicznych tekstów, które mogtyby być czytane ponad podziatami [...], czy nawet podstawowego leksykonu, dzięki któremu nie musielibyśmy za każdym razem wyważać otwartych drzwi w pierwszych przypisach, akapitach i rozdziatach naszych prac ${ }^{14}$. W czasie gdy pisał te słowa, Olick pracował już - wraz z Vered Vinitzky-Seroussi i Danielem Levym nad antologią The collective memory reader. Ukazała się ona w 2011 roku i zawiera teksty, które - zdaniem badaczy - stworzyły podstawy pod badania pamięci, choć warto zauważyć, że tylko nieliczne z nich w ogóle posługiwały się słowem "pamięć”.

Problem chaosu terminologicznego diagnozował też Wulf Kansteiner, który pisał: Szukając alternatyw do socjologicznie "skontaminowanej" koncepcji pamięci zbiorowej, badacze ukuli takie pojęcia, jak „social memory”, "collective memory”, i "popular history making" lub też zupetnie odrzucili potrzebe nowej terminologii na rzecz staromodnej koncepcji mitu. Wraz z poszukiwaniem pojęć naświetlających spoteczna podstawę lub spoteczna funkcje pamięci zbiorowych coraz bardziej rosta liczba pojęci ${ }^{15}$. Zarówno Kansteiner, jak i Olick zwracali uwagę na jeszcze jeden problem, a mianowicie na kwestię różnych metodologii. Brak wspólnego języka może być bowiem nie tyle przyczyną, ile rezultatem kłopotów z samookreśleniem się badań pamięci. Obejmują one zarówno empirycznie uchwytne opinie jednostek o przeszłości, jak i abstrakcyjne kategorie odwołujące się do ulotnego imaginarium kulturowego. Podejmując refleksję nad tym problemem, Kansteiner mówił o trudnościach w pokonaniu luki między empirycznym podejściem nauk społecznych (zwłaszcza psychologii) a kulturową wizją pamięci, która jest czymś więcej niż sumą pamięci jednostkowych ${ }^{16}$. Olick opisał tę różnicę przez wyodrębnienie dwóch pojęć: „pamięć zebrana” (collected memory) oraz „pamięć zbiorowa” (collective memory $)^{17}$.

13 Ch. Cornelißen, Czym jest kultura pamięci? Pojęcie - metody - perspektywy, przel. E. Bagłajewska-Miglus, [w:] (Kon)teksty pamięci..., s. 255.

14 J. Olick, „Collective memory”: a memoir and prospect, „Memory Studies” 2008, vol. 1, nr 1, s. 26.

15 W. Kansteiner, Szukanie znaczeń w pamięci..., s. 228.

16 Tamże.

17 J. Olick, Collective Memory: The Two Cultures, „Sociological Theory” 1999, vol. 17, nr 3, s. 333-348. 
Pamięć okazuje się zatem terminem nieostrym, co austriacko-węgierski kulturoznawca Moritz Csáky uznawał za zaletę ${ }^{18}$. Traktował pamięć nie jak typowy termin akademicki, lecz jako „figurę myśli” (nawiązanie do Benjamina nie jest tu przypadkowe), która odpowiada płynności epoki i wielości współczesnych tożsamości. Paul Ricoeur postulował z kolei, by wobec nieistnienia „pamięci zbiorowej” jako empirycznej substancji nie traktować jej w kategoriach przedmiotowych, lecz wyłącznie jako pojęcie operacyjne. Nasze dzisiejsze zmagania z tożsamościami i renesansem społeczeństw narodowych pokazują jednak, że wieloznaczne „figury myśli” i fenomenologiczne pojęcia operacyjne nie wystarczają - wciąż mamy niedosyt kategorii, by opisać współczesne przemiany społeczne i kulturowe.

\section{WYNAJDYWANIE TRADYCJI BADAŃ PAMIĘCI}

Problem badań pamięci jako dyscypliny nie wynika wyłącznie z kłopotów terminologicznych i metodologicznych, lecz także z ich niejasnej tradycji. Większość badaczy rozpoczyna swoje prace od odesłania do Maurice'a Halbwachsa. Jednak już w połowie lat 90. dwoje izraelskich badaczy, Noah Gedi i Yigal Elam, uznało, że Halbwachs jest często cytowany, ale rzadko czytany ${ }^{19}$. Przypisuje mu się - zgodnie z prawdą - popularyzację terminu „pamięć zbiorowa”, ale często pomija się fakt, że ten francuski socjolog miał na myśli coś innego niż my dziś: zwracał uwagę przede wszystkim na pamięć jednostkową i na to, że kształtuje się ona w otoczeniu społecznym, w relacjach z innymi grupami, które tworzą tzw. społeczne ramy pamięci. Tymczasem problem obecności przeszłości w teraźniejszości był przedmiotem refleksji wielu innych uczonych: Georga W.F. Hegla, Fryderyka Nietzschego, Zygmunta Freuda, Waltera Benjamina - by wymienić tylko najbardziej znane i oczywiste nazwiska. Również w polskiej humanistyce i socjologii możemy odnaleźć autorów, którzy zajmowali się społecznymi konsekwencjami historii. Wątki te obecne są u Floriana Znanieckiego, Stefana Czarnowskiego, Stanisława Ossowskiego, Antoniny Kłoskowskiej i wielu innych. Co znamienne, podobnie jak w wypadku Halbwachsa, polska refleksja wyrasta z tradycji socjologii Durkheima, który tylko sporadycznie pojawia się w panteonie ojców założycieli badań pamięci. Większość klasyków i prekursorów tego pola nie używała bowiem pojęcia „pamięć" - a jeśli, to jedynie okazjonalnie. Nietzsche wyodrębniał różne rodzaje historii ${ }^{20}$, a jego wizja „historii monumentalnej” bliska jest temu, co dziś nazwalibyśmy „pamięcią zbiorową” czy nawet „polityką pamięci”. Idea współczynnika humanistycznego Znanieckiego pozwala opisać relację między faktem historycznym a jego doświadczeniem,

18 M. Csáky, Die Mehrdeutigkeit von Gedächtnis und Erinnerung. Ein kritischer Beitrag zur historischen Gedächtnisforschung, „Virtuelle Fachbibliothek Osteuropa” 2004, nr 9, epub.ub.uni-muenchen. de/603/1/csaky-gedaechtnis.pdf, 16 VII 2018.

N. Gedi, Y. Elam, Collective memory - What is it?, „History and Memory” 1996, vol. 8, nr 1.

20

F. Nietzsche, O pożytkach i szkodliwości historii dla życia, [w:] tenże, Niewczesne rozważania, przeł. M. Łukasiewicz, Kraków 1996. 
które manifestuje się w pamięci ${ }^{21}$. Czarnowski z kolei pisał o „dawności w teraźniejszości”22, a jeszcze w latach 60. XX wieku Nina Assorodobraj mówiła o „świadomości historycznej"23, mając na myśli zjawiska, które dwie dekady później były opisywane już na ogól jako pamięć społeczna. Tego typu zbieżności widać dopiero z perspektywy czasu, gdy wiemy, jak potoczyła się historia nauki. Opisały je Kornelia Kończal i Joanna Wawrzyniak w artykule o korzeniach polskiego „pamięcioznawstwa” ${ }^{24}$. Warto się jednak zastanowić, na ile poszukiwania początków pamięcioznawstwa - by pozostać przy terminie Kończal i Wawrzyniak - nie są próbą wynajdywania tradycji dyscypliny expost. Podobne praktyki miały miejsce w studiach kultury wizualnej, gdy źródeł dyscypliny doszukiwano się m.in. w hamburskiej szkole Aby'ego Warburga - skądinąd dokładnie tego samego badacza, który wymieniany bywa jako jeden z prekursorów badań nad kulturą pamięci.

Problem wynajdywania tradycji młodej dyscypliny budzi zastrzeżenia. Badacze pamięci, którzy interesują się wykorzystywaniem historii w teraźniejszości, powinni być czuli na takie praktyki. Dlatego, odpowiadając na zadane w tytule pytanie: „Czy potrzebujemy osobnej dyscypliny?”, odpowiem: nie, jeśli mamy na myśli instytucjonalnie określoną dyscyplinę naukową; tak, ponieważ słowo „dyscyplina” odwołuje się do porządku i rygoru naukowego ${ }^{25}$. Potencjał badań pamięci, który polega na tym, że prowadzone są one na pograniczu dyscyplin, w krzyżujących się polach, z wykorzystaniem wielu teorii i tradycji, może być zarazem ich przekleństwem. Łatwo bowiem z interdyscyplinarności uczynić wytrych do nader swobodnych i arbitralnych interpretacji. Dlatego Reinhart Koselleck, który był krytycznym świadkiem niemieckiego zwrotu pamięciowego, dopominał się, by nie traktować pamięci jako arbitralnego narzędzia, lecz zawsze zadawać trzy fundamentalne pytania: „Kto pamięta?”, „Co jest pamiętane?”, "Jak jest pamiętane?"26. Prosta reguła Kosellecka pozwala zachować analityczny porządek i dyscyplinę myślenia w mglistym obszarze badań pamięci.

\section{CO PO PAMIĘCI?}

Pod koniec XX wieku niewielu badaczy podzielało czujność Kosellecka. Na przełomie tysiącleci wydawało się, że dotarliśmy do końca historii; „pamięć”, a zwłaszcza „kultura pamięci”, były atrakcyjnymi terminami, które pozwalały mówić o przeszłości,

$21 \quad$ K. Łukasiewicz, Wspótczynnik humanistyczny, [w:] Modi memorandi...

22 E. Tarkowska, Dawność w teraźniejszości, [w:] Modi memorandi...

23 V. Julkowska, Świadomość historyczna, [w:] Modi memorandi...

24 K. Kończal, J. Wawrzyniak, Polskie badania pamięcioznawcze....; K. Kończal, J. Wawrzyniak, Provincializing memory studies: Polish approaches to the past in the present, „Memory Studies” 2017, vol. 11, nr 4 .

25 Problem ten dyskutowany był przede wszystkim przez kulturoznawców. Por. Kulturo-znawstwo. Dyscyplina bez dyscypliny?, red. W.J. Burszta, M. Januszkiewicz, Warszawa 2010.

26 Por. na ten temat przełomowe studium Kosellecka o analizie pomników: R. Koselleck, Kriegerdenkmale als Identitätsstiftungen der Überlebenden, [w:] Identität, red. O. Marquard, K. Stierle, München 1979. 
koncentrując się na jej kulturowych reprezentacjach, nierzadko z porzuceniem metodologicznego rygoru nauk historycznych i społecznych. Na tej fali powstało wiele odważnych interpretacji, łączących przeszłość z teraźniejszością. Dziś wiemy jednak, że końca historii nie było. Historia dzieje się nadal. Zwłaszcza w obliczu manipulacji przeszłością, zdyscyplinowane badanie historii okazuje się niezbędne. Dotyczy to nie tylko dochodzenia do tego, co i jak wydarzyło się kiedyś, ale także zrozumienia, jak wykorzystuje się przeszłość. Koselleckowe pytania o to, kto, co i jak pamięta, można uzupełnić o czwarte: dlaczego pamięta?

Problem funkcjonalności przeszłości w teraźniejszości ma coraz większe znaczenie polityczne, społeczne, kulturowe. Historia staje się coraz istotniejszym elementem sfery publicznej, mediów masowych, a nawet rynku ${ }^{27}$. W marcu 2018 roku, kiedy pisałam te słowa, na Dworcu Centralnym w Warszawie wisiały reklamy zachęcające do udziału w obchodach dnia tzw. żołnierzy wyklętych. Sieciowy bar z kawą i kanapkami na tymże dworcu wystylizowany był tak, żeby wyglądał na znacznie starszy. Gazetka w pociągu zachwalała polskie zabytki i tradycyjną (co trzeba podkreślić) polską kuchnię. Wszystko to dotyczy obecności przeszłości w teraźniejszości, ale ma niewiele wspólnego z pamięcią. Podam jeszcze jeden przykład: w 2017 roku, zanim wyburzono i ponownie zrekonstruowano warszawską Rotundę, przez kilkanaście miesięcy zdobiły ją ogromne banery: w marcu z wizerunkiem tzw. żołnierzy wyklętych, w maju z fragmentem Konstytucji 3 maja, latem ze wspomnieniem powstania warszawskiego i wreszcie jesienią z fotografią i sloganem odwołującym się do odzyskania niepodległości w 1918 roku. Jedna z większych polskich instytucji finansowych (bank PKO BP) wykorzystała zatem w kampanii reklamowej fundamentalne wydarzenia polskiej historii. Rzecz działa się w ścisłym centrum Warszawy, na jednej najdroższych nieruchomości w Polsce. Ponieważ bank ten kontrolowany jest przez Skarb Państwa, sprawa ma charakter polityczny, ale też oczywiście społeczny, bo nie było w tym czasie chyba warszawiaka (o warszawskich klientach banku nie wspominając), który nie widziałby tych obrazów. Wykorzystano fragmenty archiwalnych zdjęć, opatrzono je współczesnymi sloganami reklamowymi. Aby rzetelnie opisać to relatywnie niewielkie zdarzenie, potrzeba kompetencji historycznych, kulturoznawczych, socjologicznych, politologicznych, ekonomicznych czy prawniczych, natomiast pojęcie pamięci niewiele wniesie do takiej analizy. W Niemczech, gdzie zwrot pamięciowy zatoczył wyjątkowo szerokie koło, od kilku lat obserwujemy zmęczenie zwrotem pamięciowym, mimo że - podobnie jak w Polsce - przeszłość jest coraz bardziej widocznym elementem teraźniejszości. Naukowcy rzadziej mówią tam o pamięci, a częściej o historii w przestrzeni publicznej, historii stosowanej lub public history. W tych ostatnich dwóch kierunkach, czyli historii stosowanej i public history, można nawet się kształcić na kilku uniwersytetach - w tym tak prestiżowych, jak Uniwersytet w Heidelbergu czy Wolny Uniwersytet w Berlinie. Od niedawna także w Polsce oferowane są studia z zakresu public history, np. na Uniwersytecie Wrocławskim. Nie bez przyczyny wszystkie te pojęcia mają historię w nazwie. Być może właśnie powrót do

27 Por. M. Řezník i in., Historia w późnym kapitalizmie. Wprowadzenie, [w:] Historia w kulturze ponowoczesnej. Koncepcje - metody - perspektywy badawcze, red. M. Řezník i in., Kraków 2018. 
historii - w nowych odsłonach teoretycznych i nowych, zmodernizowanych wariantach metodologicznych - jest kierunkiem, w którym zmierzamy po badaniach pamięci.

\section{BIBLIOGRAFIA}

Assmann J., Pamięć kulturowa. Pismo, zapamiętywanie ipolityczna tożsamość w cywilizacjach starożytnych, przel. A. Kryczyńska-Pham, Warszawa 2008.

Bachmann-Medick D., Cultural Turns. Nowe kierunki w naukach o kulturze, przeł. K. Krzemieniowa, Warszawa 2012.

Bal M., Wizualny esencjalizm i przedmiot kultury wizualnej, przeł. M. Bryl, „Artium Quaestiones" 2006, nr 17.

Connerton P., Jak spoteczeństwa pamiętają?, przeł. M. Napiórkowski, Warszawa 2012, https:// doi.org/10.31338/uw.9788323520023.

Cornelißen Ch., Czym jest kultura pamięci? Pojęcie - metody - perspektywy, przeł. E. Bagłajewska-Miglus, [w:] (Kon)teksty pamięci. Antologia, red. K. Kończal, Warszawa 2014.

Csáky M., Die Mehrdeutigkeit von Gedächtnis und Erinnerung. Ein kritischer Beitrag zur historischen Gedächtnisforschung, „Virtuelle Fachbibliothek Osteuropa” 2004, nr 9, epub.ub.uni-muenchen.de/603/1/csaky-gedaechtnis.pdf, 16 VII 2018.

Erll A., Kultura pamięci. Wprowadzenie, przet. A. Teperek, Warszawa 2018, https://doi. org/10.31338/uw.9788323534174.

Gedi N., Elam Y., Collective memory - What is it?, „History and Memory” 1996, vol. 8, nr 1.

Julkowska V., Świadomość historyczna, [w:] Modi memorandi. Leksykon kultury pamięci, red. M. Saryusz-Wolska, R. Traba, współpr. J. Kalicka, Warszawa 2014.

Kansteiner W., Szukanie znaczeń w pamięci: metodologiczna krytyka pamięcioznawstwa, [w:] (Kon)teksty pamięci. Antologia, red. K. Kończal, Warszawa 2014.

Kończal K., Wprowadzenie, [w:] (Kon)teksty pamięci. Antologia, red. taż, Warszawa 2014.

Kończal K., Wawrzyniak J., Polskie badania pamięcioznawcze: tradycje, koncepcje, (nie)ciagtości, „Kultura i Społeczeństwo” 2011, nr 4.

Kończal K., Wawrzyniak J., Provincializing memory studies: Polish approaches to thepast in the present, „Memory Studies” 2017, vol. 11, nr 4, https://doi.org/10.1177/1750698016688238.

Koselleck R., Kriegerdenkmale als Identitätsstiftungen der Überlebenden, [w:] Identität, red. O. Marquard, K. Stierle, München 1979.

Kulturo-znawstwo. Dyscyplina bez dyscypliny?, red. W.J. Burszta, M. Januszkiewicz, Warszawa 2010.

Łukasiewicz K., Wspótczynnik humanistyczny, [w:] Modi memorandi. Leksykon kultury pamięci, red. M. Saryusz-Wolska, R. Traba, współpr. J. Kalicka, Warszawa 2014.

Mirzoeff N., Podmiot kultury wizualnej, przel. M. Bryl, „Artium Quaestiones” 2006, nr 17.

Mitchell W.J.T., Pokazujac widzenie: krytyka kultury wizualnej, przeł. M. Bryl, „Artium Quaestiones" 2006, nr 17.

Mitchell W.J.T., Zwrot piktorialny, przeł. M. Drabek, „Kultura Popularna” 2009, nr 1.

Modi memorandi. Leksykon kultury pamięci, red. M. Saryusz-Wolska, R. Traba, współpr. J. Kalicka, Warszawa 2014. 
Nietzsche F., Opożytkach i szkodliwości historii dla życia, [w:] F. Nietzsche, Niewczesne rozważania, przeł. M. Łukasiewicz, Kraków 1996.

Olick J., „Collective memory”: a memoir and prospect, „Memory Studies” 2008, vol. 1, nr 1, https://doi.org/10.1177/1750698007083885.

Olick J., Collective Memory: The Two Cultures, „Sociological Theory” 1999, vol. 17, nr 3, https://doi.org/10.1111/0735-2751.00083.

Řezník M. i in., Historia w późnym kapitalizmie. Wprowadzenie, [w:] Historia w kulturze ponowoczesnej. Koncepcje - metody - perspektywy badawcze, red. M. Řezník i in., Kraków 2018.

Saryusz-Wolska M., Wprowadzenie, [w:] Pamięć zbiorowa i kulturowa. Wspótczesna perspektywa niemiecka, red. M. Saryusz-Wolska, Kraków 2009.

Szacka B., O pamięci spotecznej, „Znak” 1995, nr 5.

Tarkowska E., Dawność w teraźniejszości, [w:] Modi memorandi. Leksykon kultury pamięci, red. M. Saryusz-Wolska, R. Traba, współpr. J. Kalicka, Warszawa 2014.

Traba R., Hahn H.H., O czym (nie) opowiadaja polsko-niemieckie miejsca pamięci, [w:] Polsko-niemieckie miejsca pamięci, t. 1, red. R. Traba, H.H. Hahn, współpr. K. Kończal, M. Górny, Warszawa 2015.

Dr hab. Magdalena SARYUSZ-WOLSKA - adiunkt w Instytucie Kultury Współczesnej Uniwersytetu Łódzkiego, w latach 2010-2019 pracowała najpierw w Centrum Badań Historycznych Polskiej Akademii Nauk w Berlinie, a następnie w Niemieckim Instytucie Historycznym w Warszawie. Obecnie stypendystka im. Alexandra von Humboldta na Uniwersytecie im. Jana Gutenberga w Moguncji. Autorka książki Spotkania czasu z miejscem. Studia o pamięci i miastach (2011), redaktorka i współredaktora wielu opracowań zbiorowych, w tym: Pamięć zbiorowa i kulturowa. Wspótczesna perspektywa niemiecka (2009) oraz Modi memorandi. Leksykon kultury pamięci (2014). Publikowata m.in. w „Osteuropa”, „German Life and Letters” oraz „Participations. Journal of Audience and Reception Studies". 